ISSN 2413-0877 Volume 2 (2015) 203-212

The 3rd International Conference on Biological Science 2013

(The 3rd ICBS-2013)

\title{
SPATIAL ANALYSIS ON PHYTOPLANKTON IN GREEN MUSSEL AQUACULTURE AREA, KAMAL MUARA, NORTH JAKARTA
}

\author{
Abdul Basir, Riani Widiarti, Wisnu Wardhana \\ Department of Biology, Faculty of Mathematics and Natural Science, \\ Universitas Indonesia \\ Email: abdul.basir@mail.com
}

\begin{abstract}
Research on the spatial distribution of phytoplankton was held in the green mussel aquaculture area, Kamal Muara, North Jakarta. The research aimed to obtain the abundance and spatial distribution of phytoplankton and the influencing environmental parameters. The study was necessary to conduct in order to determine the useful or harmful phytoplankton groups in the location, which will affect the quality of green mussel for consumption. Thalasiossira and Chaetoceros from Bacillariophyceae, which will be harmful in a bloom condition, were the most abundantly found phytoplankton in the area. Based on distribution maps, the abundance of Bacillariophyceae and Dinophyceae were highest at stations near the mainland, whereas Cyanophyceae was at farther stations. Spearman's correlation values indicated that the abundance of Bacillariophyceae was most influenced by $\mathrm{pH}$, Dinophyceae by salinity, whereas Cyanophyceae was influenced by phosphate.
\end{abstract}

Key words: Kamal Muara, phytoplankton, spatial distribution.

\section{INTRODUCTION}

Phytoplankton are unicellular planktonic-aquatic organisms that are able to produce oxygen and organic material that can be utilized by other organisms (Suthers \& Rissik, 2008; Gross, 1990). In addition to their positive impact, phytoplankton also have negative impacts that produce toxins or cause a depletion of oxygen in water, which can cause mass mortality in marine aquaculture businesses and threaten human health (Prayitno, 2011).

One area in Indonesian waters with high phytoplankton abundance is Jakarta Bay, due to high terrigenous input through 13 river mouths that pass through Jakarta (Prayitno, 2011). The phytoplankton abundance in Jakarta Bay is utilized by people around the bay for the cultivation of green mussel (Perna viridis). One of the green mussel aquaculture areas is in Kamal Muara, North Jakarta, which is located in the western part of Jakarta Bay. Green mussel cultivation is the main occupation of the people of Kamal Muara (DPPK Provinsi DKI Jakarta, 2006).

It is important to know the abundance and spatial distribution of phytoplankton in the green mussel aquaculture area (Perna viridis), Kamal Muara, North Jakarta. Phytoplankton abundance, from species that are beneficial or harmful in the aquaculture area, is closely related to the quality of green mussel that be consumed by humans. Phytoplankton abundance of useful species, such as Chaetoceros from class Bacillariophyceae, are a good food source for the green mussel. Harmful phytoplankton, for example Alexandrium from class Dinophyceae, can cause mass death of aquaculture biota and threaten human health (Hallegraeff, 1991; Kurniawan, 2008; Prayitno, 2011).

This research aims to determine the abundance and spatial distribution of phytoplankton in

ISSN 2413-0877 (C) 2015 The Authors.

Published by KnowledgeE Publishing Services This is an open access article under the CC BY-NC-ND license (http://creativecommons.org/licenses/by-nc-nd/4.0)

Selection and Peer-review under responsibility of the 3rd ICBS-2013

Doi http://dx.doi.org/10.18502/kls.v2i1.144 
the green mussel (Perna viridis) aquaculture area, Kamal Muara, North Jakarta, as well as the parameters that influenced it. The results of the research can be used as basic information in the implementation of a surveillance (monitoring) of the quality of water in the Kamal Muara green mussel aquaculture area.

\section{MATERIALS AND METHODS}

\section{Time and location of the research}

Plankton samples were taken at nine stations in the waters of the green mussel aquaculture area, Kamal Muara, North Jakarta (Figure 1) in May 2012.

\section{Tools and Materials}

The tools and materials used was a plankton net (mesh size $20 \mathrm{~lm}$ ), sample bottles, $40 \%$ formalin, thermometer, hand refractometer, $\mathrm{pH}$ indicator paper, secchi disk, DO meter, flow measuring devices, Global Positioning System (GPS), Sedgewick-rafter cell, Pasteur pipette, and light microscopy.

\section{Phytoplankton sampling and enumeration}

Sampling was conducted using a plankton net that was drawn vertically from a depth of 2 meters. Plankton samples that had been collected in the reservoir bottle were then poured into the sample bottle. Samples were then given a $40 \%$ formalin as much as $5 \mathrm{ml}$. The preserved sample was then dripped into the Sedgewick-rafter cell. Enumeration was done under a microscope at 10×10 magnification.

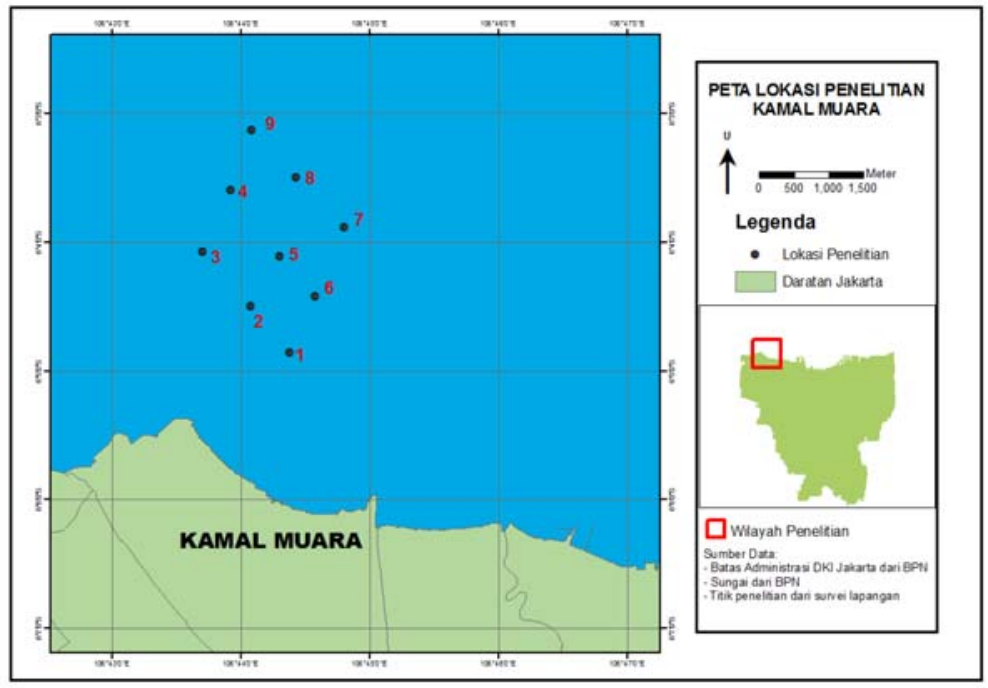

Figure 1. Sampling location map,

\section{Measurement of environmental parameters}

Environmental parameters measured were temperature, salinity, acidity $(\mathrm{pH})$, dissolved oxygen (DO), light intensity, brightness, depth, and current velocity. Environmental parameter measurement data was then tabulated and analyzed to determine the environmental parameters that influenced the abundance of phytoplankton. 


\section{Data analysis}

The spatial distribution of phytoplankton and environmental parameters was mapped using Geographic Information System (GIS) software. The correlation between phytoplankton abundance and environmental parameters was analyzed using the software Statistical Product and Service Solutions (SPSS) using Multivariate Regression analysis.

\section{RESULT AND DISCUSSION}

Phytoplankton group abundance and its frequency in the sampling sites is presented in Table 1. Phytoplankton groups found in the research came from three classes: Bacillariophyceae, Dinophyceae, and Cyanophyceae.

\section{Distribution map of phytoplankton abundance}

Based on distribution maps, Bacillariophyceae and Dinophyceae abundance was highest at the station closer to the mainland, especially Stations 1 and 2. Bacillariophyceae abundance distribution maps in the study site can be seen in Figure 2 and the distribution maps of Dinophyceae abundance in the study site can be seen in Figure 3.

Stations that are closer to the mainland get a high amount of nutrients from the estuaries as a result of human activities. Areas that are close to the mainland have high productivity because of the large input of land through runoff events (Parsons et al., 1984). Sampling phosphate and nitrate in the estuary showed that phosphate and nitrate content is higher in the estuary. Phosphate content measured at the estuary reached $6.98 \mathrm{mg} / \mathrm{l}$ and nitrate reached $1.41 \mathrm{mg} / \mathrm{l}$.

The Bacillariophyceae abundance distribution maps illustrated that besides at Stations 1 and 2, the high abundance of Bacillariophyceae also occurred in Station 9 with a total of 8,397 cells/liter. Bacillariophyceae abundance is related to the abundance of Thalassiosira and Chaetoceros genera, the abundance of which was 7,351 cells/liter and 795 cells/liter, respectively. Station 9 is far the station so get less effect of nutrient inputs from land. Genera Thalassiosira and Chaetoceros are known to grow abundantly at Station 9 due to their ability to survive in environmental conditions with high or low nutrients. Research conducted by McGinnis et al. (1997) suggests that Thalassiosira and Chaetoceros can grow abundantly in conditions where phosphate and nitrate contents are low, whereas other phytoplankton growth will be stunted. Certain species of Thalassiosira and Chaetoceros, like Thalassiosira spp. and $C$. concavircornis can be harmful to other biota and the environment in terms of causing fish gill irritation and oxygen depletion (Anderson et al., 2001)

Dinophyceae abundance in the sampling sites was also the highest at Station 1 and Station 2, with the abundance of each being 1,308 cells/liter and 929 cells/liter, respectively, which was mainly due to the abundance of genera Ceratium and Protoperidinium. The findings of both genera as the most abundant in the sampling sites was in accordance with Gomez (2005), which states that the genera Ceratium and Protoperidiniumis were an example of class Dinophyceae genera that are common in the ocean. Ceratiumfusus, one common species of Ceratium, can cause gill irritation, and also affects oyster larvae and shrimp. Intensify management and mitigation of the effect of Ceratiumfusus abundance is poorly understood (Anderson et al., 2001). 
Table1. Phytoplankton abundance and frequency of phytoplankton in the sampling sites.

\begin{tabular}{|c|c|c|c|c|c|c|c|c|c|c|c|}
\hline & & & & & ATION & & & & & & \\
\hline GENUS & 1 & 2 & 3 & 4 & 5 & 6 & 7 & 8 & 9 & Total & $\begin{array}{l}\text { Frequency } \\
(\%)\end{array}$ \\
\hline \multicolumn{12}{|l|}{ BACILLARIOPHYCEAE } \\
\hline \multicolumn{12}{|l|}{ Ordo Centrales } \\
\hline Chaetoceros & 948 & 469 & 894 & 178 & 512 & 1369 & 1865 & 765 & 795 & 7795.0 & 100 \\
\hline Coscinodiscus & 20 & 9 & 8 & 8 & 9 & 11 & 9 & 8 & 0 & 82.0 & 88.89 \\
\hline Hemidiscus & 16 & 8 & 6 & 2 & 5 & 15 & 3 & 7 & 0 & 62.0 & 89 \\
\hline Melossira & 0 & 1 & 0 & 15 & 78 & 0 & 0 & 38 & 0 & 132.0 & 44.44 \\
\hline Rhizosolenia & 13 & 8 & 8 & 2 & 18 & 6 & 3 & 2 & 23 & 83.0 & 100 \\
\hline Skeletonema & 107 & 119 & 104 & 38 & 84 & 61 & 133 & 97 & 191 & 934.0 & 100 \\
\hline Thalasiossira & 8040 & 10962 & 2221 & 2863 & 1357 & 3238 & 913 & 2645 & 7351 & 39590.0 & 100 \\
\hline Total Centrales & 9144 & 11576 & 3241 & 3106 & 2063 & 4700 & 2926 & 3562 & 8360 & 48678.0 & \\
\hline \multicolumn{12}{|l|}{ Ordo Pennales } \\
\hline Dactyliosolen & 0 & 0 & 1 & 0 & 0 & 0 & 0 & 1 & 0 & 2.0 & 22.22 \\
\hline Gyrosigma & 0 & 0 & 2 & 1 & 0 & 12 & 1 & 1 & 2 & 19.0 & 66.67 \\
\hline Helicotheca & 4 & 2 & 9 & 2 & 6 & 4 & 1 & 5 & 4 & 37.0 & 100 \\
\hline Lauderia & 0 & 0 & 1 & 3 & 0 & 3 & 0 & 2 & 0 & 9.0 & 44.44 \\
\hline Navicula & 0 & 1 & 0 & 0 & 0 & 2 & 0 & 1 & 0 & 4.0 & 33.33 \\
\hline Nitszchia & 0 & 0 & 1 & 0 & 1 & 0 & 0 & 1 & 1 & 4.0 & 44.44 \\
\hline Pleurosigma & 1 & 2 & 0 & 2 & 1 & 4 & 0 & 1 & 0 & 11.0 & 66.67 \\
\hline Pseudonitzschia & 108 & 260 & 140 & 21 & 19 & 7 & 36 & 19 & 20 & 630.0 & 100 \\
\hline Thalassionema & 10 & 6 & 2 & 0 & 1 & 4 & 3 & 2 & 10 & 38.0 & 88.89 \\
\hline Total Pennales & 123 & 271 & 156 & 29 & 28 & 36 & 41 & 33 & 37 & 754.0 & \\
\hline TOTAL BACILLARIOPHYCEAE & 9267 & 11847 & 3397 & 3135 & 2091 & 4736 & 2967 & 3595 & 8397 & 49432.0 & \\
\hline \multicolumn{12}{|l|}{ DINOPHYCEAE } \\
\hline \multicolumn{12}{|l|}{ Ordo Dinophysiales } \\
\hline Dinophysis & 3 & 2 & 2 & 0 & 1 & 5 & 8 & 1 & 1 & 23.0 & 88.89 \\
\hline Total Dinophysiales & 3 & 2 & 2 & 0 & 1 & 5 & 8 & 1 & 1 & 23.0 & \\
\hline \multicolumn{12}{|l|}{ Ordo Peridiniales } \\
\hline Ceratium & 576 & 628 & 208 & 220 & 88 & 208 & 548 & 194 & 319 & 2989.0 & 100 \\
\hline Gonyaulax & 20 & 32 & 4 & 1 & 3 & 1 & 0 & 0 & 3 & 64.0 & 77.78 \\
\hline Protoperidinium & 665 & 235 & 187 & 21 & 41 & 115 & 77 & 73 & 106 & 1520.0 & 100 \\
\hline Pyrophacus & 41 & 32 & 51 & 11 & 11 & 15 & 19 & 7 & 2 & 189.0 & 100 \\
\hline Total Peridiniales & 1302 & 927 & 450 & 253 & 143 & 342 & 644 & 274 & 430 & 4765.0 & \\
\hline \multicolumn{12}{|l|}{ Ordo Prorocentrales } \\
\hline Prorocentrum & 2 & 0 & 4 & 3 & 4 & 0 & 3 & 2 & 0 & 18.0 & 66.67 \\
\hline Total Prorocentrales & 2 & 0 & 4 & 3 & 4 & 0 & 3 & 2 & 0 & 18.0 & \\
\hline \multicolumn{12}{|l|}{ Ordo Gymdodiniales } \\
\hline Gymnodinium & 1 & 0 & 2 & 6 & 3 & 0 & 0 & 12 & 2 & 26.0 & 66.67 \\
\hline Total Gymnodiniales & 1 & 0 & 2 & 6 & 3 & 0 & 0 & 12 & 2 & 26.0 & 66.67 \\
\hline TOTAL DINOPHYCEAE & 1308 & 929 & 458 & 262 & 151 & 347 & 655 & 289 & 433 & 4832.0 & \\
\hline \multicolumn{12}{|l|}{ CYANOPHYCEAE } \\
\hline Arthospira & 2 & 0 & 1 & 1 & 1 & 1 & 0 & 0 & 0 & 6.0 & 44.44 \\
\hline Trichodesmium & 0 & 0 & 0 & 5 & 15 & 0 & 0 & 0 & 15 & 35.0 & 33.33 \\
\hline TOTAL CYANOPHYCEAE & 2 & 0 & 1 & 6 & 16 & 1 & 0 & 0 & 15 & 41.0 & \\
\hline TOTAL PHYTOPLANKTON & 10577 & 12776 & 3856 & 3403 & 2258 & 5084 & 3622 & 3884 & 8845 & 54305.0 & \\
\hline
\end{tabular}




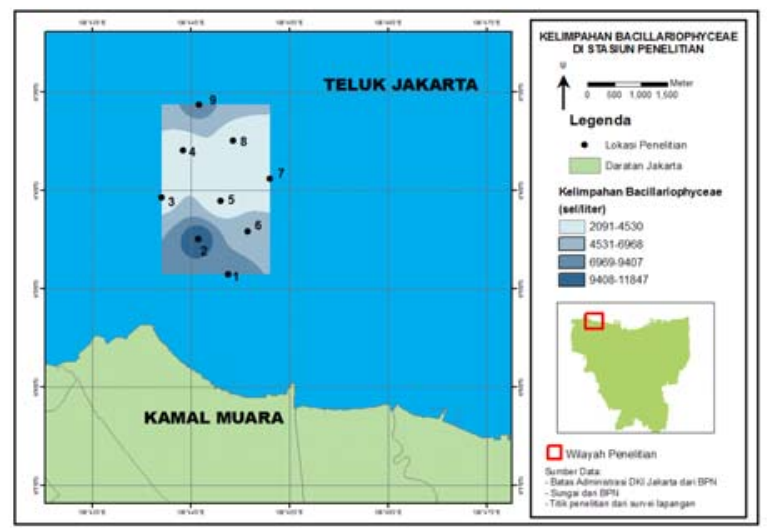

Figue 2. Bacillariophyceae abundance distribution map.

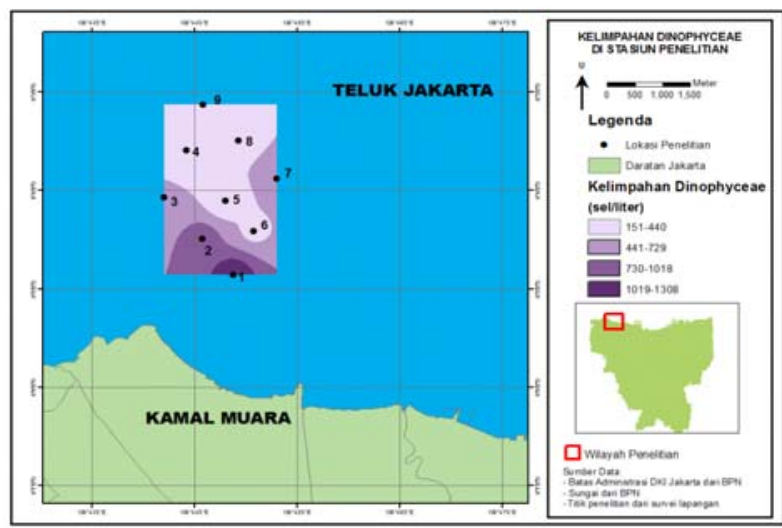

Figure 3. Dinophyceae abundance distribution map

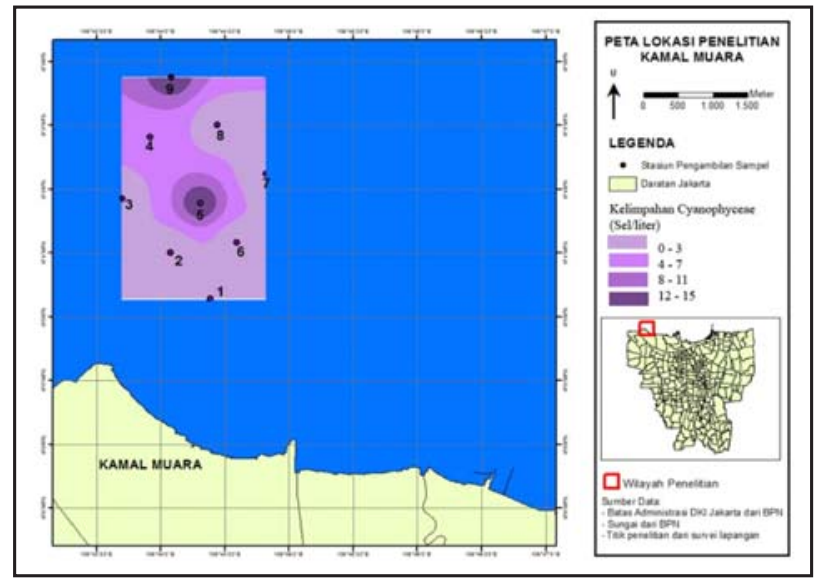

Figure 4. Cyanophyceae abundance distribution map.

Cyanophyceae had a much lower abundance than Bacillariophyceae and Dinophyceae. Cyanophyceae total abundance in the sampling sites was 41 cells/liter. In contrast to classes Bacillariophyceae and Dinophyceae, Cyanophyceae was not present in the stations close to the mainland. Based on the distribution maps, phytoplankton abundance from the Cyanophyceae class is highest at stations far from the shoreline, especially at Station 5 and Station 9 (Figure 4). This is caused by genus Trichodesmium that had the highest abundance in the sampling sites, which is an oceanic species that tends to be more abundant in waters far from land.

\section{Distribution map of environmental parameters}

Data of environmental parameters measured at sampling sites can be seen in Table 3, while the distribution map environmental parameters can be seen in Figures 5-12.

The concentration of phosphate and nitrate were higher in eastern stations (Stations 6 and 7), associated with the flow pattern in the study site in general that moves from east to west, so that the nutrients from the Jakarta mainland stations were carried over to the east (Figures 5 and 6).

The distribution map of salinity, $\mathrm{pH}$, and brightness is generally lower in the stations close to the mainland (Figure 7, 8, and 9). According to Hadikusumah (2008), the value of salinity in the Bay of Jakarta in estuaries is lower because of the influence of freshwater input. The farther of such location from the influence of the mainland, the higher the $\mathrm{pH}$ value 
Table 3. Environmental parameters measured at the sampling sites.

\begin{tabular}{|c|c|c|c|c|c|c|c|c|c|}
\hline \multirow{2}{*}{$\begin{array}{l}\text { Environmental } \\
\text { Parameters }\end{array}$} & \multicolumn{9}{|c|}{ Station } \\
\hline & 1 & 2 & 3 & 4 & 5 & 6 & 7 & 8 & 9 \\
\hline Phosphate (mg/litre) & 3.23 & 1.81 & 1.74 & 1.09 & 1.05 & 3.88 & 3.28 & 3.04 & 0.62 \\
\hline Nitrate (mg/liter) & 0.04 & 0.02 & 0.03 & 0.02 & 0.02 & 0.06 & 0.06 & 0.05 & 0.03 \\
\hline Silicate (mg/liter) & $<10$ & $<10$ & $<10$ & $<10$ & $<10$ & $<10$ & $<10$ & $<10$ & $<10$ \\
\hline Salinity (\%o) & 20 & 23 & 22 & 23 & 24 & 23 & 12 & 24 & 20 \\
\hline $\mathrm{pH}$ & 6.1 & 7 & 8 & 8 & 7 & 6.5 & 8 & 7 & 7 \\
\hline Temperature $\left({ }^{\circ} \mathrm{C}\right)$ & 31.4 & 32 & 32 & 31.4 & 32.2 & 31.7 & 31.7 & 31.3 & 31.5 \\
\hline Dissolved Oxygen (ppm) & 4.2 & 14.3 & 3.4 & 14.5 & 14.5 & 4.3 & 5.4 & 5.7 & 3.2 \\
\hline Light Intensity (Luks) & 92.3 & 138.6 & 141.4 & 138.1 & 126.6 & 93.4 & 126.7 & 122.6 & 140.5 \\
\hline Brightness (m) & 0.9 & 2.6 & 1.43 & 2.35 & 2.5 & 3.37 & 2 & 3.13 & 3.15 \\
\hline Depth (m) & 6 & 4.9 & 4.52 & 4.12 & 7 & 7.34 & 9 & 7.56 & 5.96 \\
\hline
\end{tabular}

can be as the result of terrigenous input from the mouth of the river, which makes the $\mathrm{pH}$ tend to be lower (Parsons et al., 1984). In addition to $\mathrm{pH}$, terrigenous input is also related to the brightness level of the waters. The brightness value also depends on the measurement time and weather conditions (Asmara, 1999). The intensity of light depicts the sampling time during which the light intensity was higher (Figure 10).

Research stations located on the west (Stations 2, 3, and 5) generally had a higher temperature (Figure 11). It is thought to be due to higher activity in the industrial area of Tangerang, where there are roughly 2,200 small to large-scale industries and about $71 \%$ of them dispose of waste in the rivers, which is then carried by the currents (Puspiptek, 2013). DO parameters were generally higher in the middle stations (Stations 2, 5, and 4) (Figure 12 ), and is associated with the absence of mussel aquaculture fishing platforms at these locations so that metabolic activity and respiration by biota cultivation is reduced. The absence of fishing platforms at Station 2, Station 4, and 5 stations is due to the area being designated for boat traffic and fishing boats.

\section{Relationship of phytoplankton abundance and environmental parameters}

Based on Spearman's correlation matrix for phytoplankton abundance with all the environmental parameters measured, it was found that the abundance of Bacillariophyceae was more influenced by $\mathrm{pH}$, the abundance of Dinophyceaemore was influenced by salinity, and the abundance of Cyanophyceae was more influenced by phosphate. Spearman's correlation values for Bacillariophyceae, Dinophyceae, and Cyanophyceae were $-0.541,-0.701$, and -0.672 , respectively. Spearman's correlation matrix between phytoplankton abundance with each measured environmental parameters can be seen in Table 4.

Table 4. Spearman's correlation matrix between the abundance of Bacillariophyceae, Dinophyceae, and Cyanophyceae and environmental parameters.

Spearman's Correlation Value (R)

\begin{tabular}{llllllllll}
\hline Parameter & Tem & Lig & pH & Sal & Pos & Nit & DO & Bri & Dep \\
\hline Bac & -0.127 & 0.05 & -0.541 & -0.256 & 0.133 & -0.017 & -0.485 & 0.033 & -0.317 \\
Din & 0 & 0.033 & -0.204 & -0.701 & 0.417 & -0.017 & -0.485 & -0.417 & -0.017 \\
Cya & 0.121 & 0.043 & -0.136 & 0.079 & -0.672 & -0.48 & 0 & -0.009 & -0.366 \\
\hline
\end{tabular}


The correlation values indicate that the abundance of Bacillariophyceae classes are more influenced by $\mathrm{pH}$ with the value of $\mathrm{R}-0.541$. This value indicates that higher $\mathrm{pH}$ values in the water would tend to decrease the abundance of Bacillariophyceae. Bacillariophyceae abundance distribution maps (Figure 2) and the $\mathrm{pH}$ distribution map (Figure 8) illustrate that Bacillariophyceae was generally more abundant in the low $\mathrm{pH}$ range $(6,1-7,0)$, especially at Stations 1,2 , and 9 , with an abundance of 9,267 cells/liter, 11,847 cells/liter, and 8,397 cells/ liter, respectively.

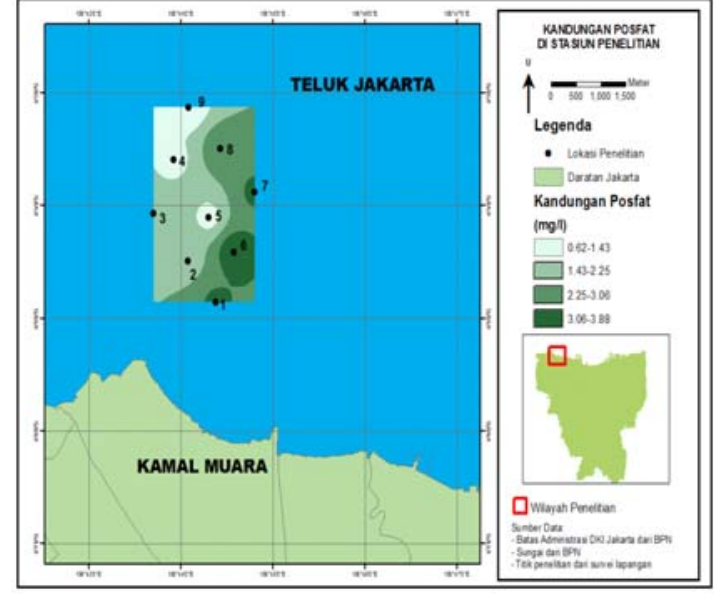

Figure 5. Phosphate concentration distribution map

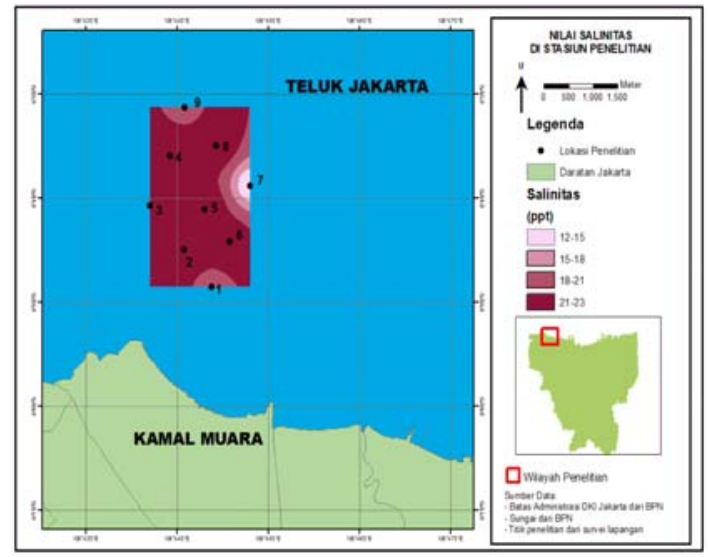

Figure 7. Salinity distribution map.

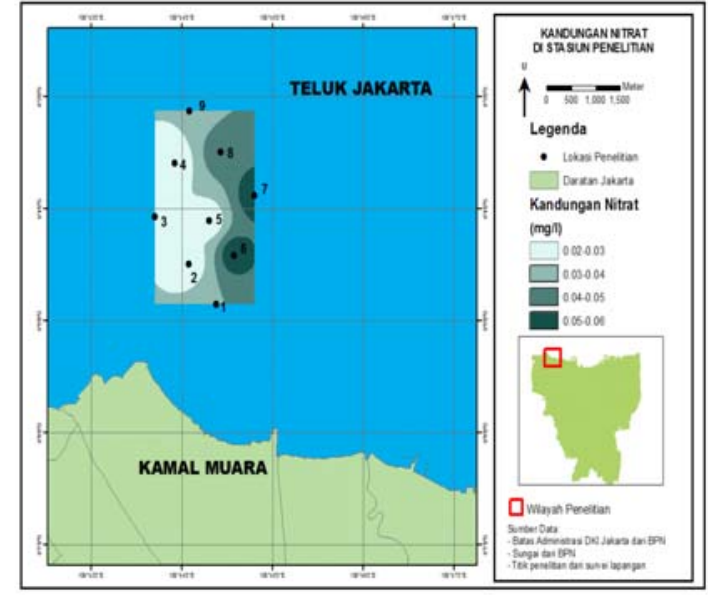

Figure 6. Nitrate concentration distribution map

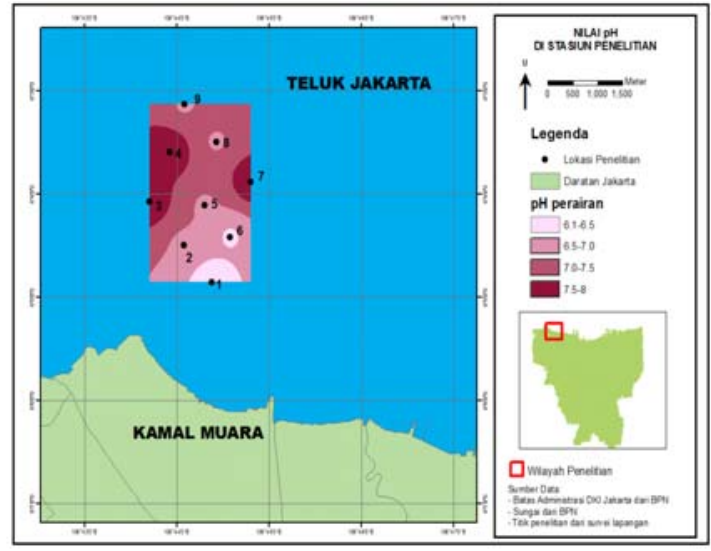

Figure 8. pH distribution map

Based on its correlation value, Dinophyceae abundance in the sampling sites is more influenced by salinity, with an $R$ value of -0.701 . This value indicates that with higher salinity in the waters at the sampling sites, Dinophyceae abundance will tend to decline. Dinophyceae abundance distribution maps (Fig. 3) and salinity distribution maps (Fig. 7) illustrates that Dinophyceae was generally more abundant at stations that have lower salinity $(12 \%-18 \%$ ), especially at Station 1 and Station 7, which had an abundance of 1,308 cells/liter and 655 cells/liter, respectively. Salinity at Station 1 and Station 7 was also lower than most of the other stations, with $20 \%$ and $12 \%$, respectively. The abundance and distribution of Dinophyceae is strongly associated with the factors of temperature, salinity, light intensity, nutrients, and flow. Among these factors, temperature and salinity are important factors in 
the development and occurrence of blooming Dinophyceae in oceans and estuaries (Su et al., 1993).

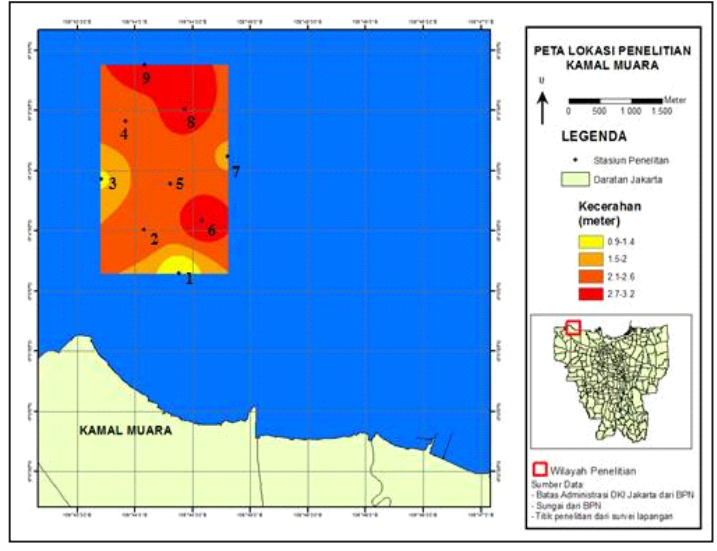

Figure 9. Brightness distribution map.

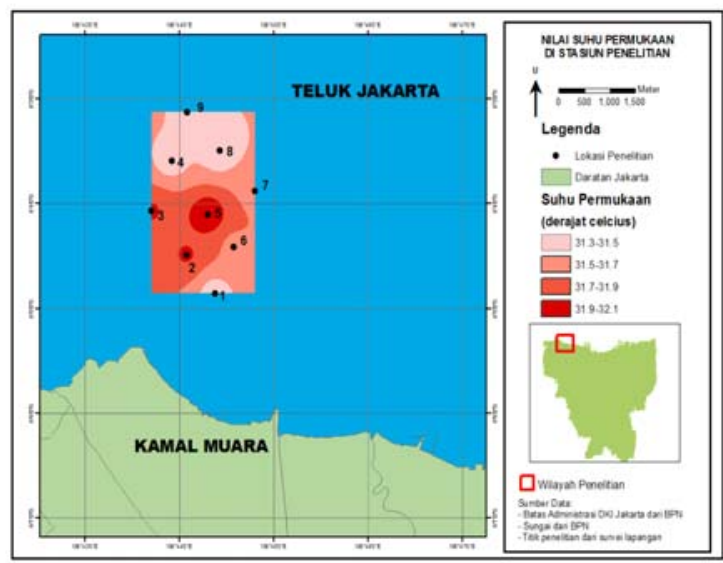

Figure 11. Temperature distribution map.

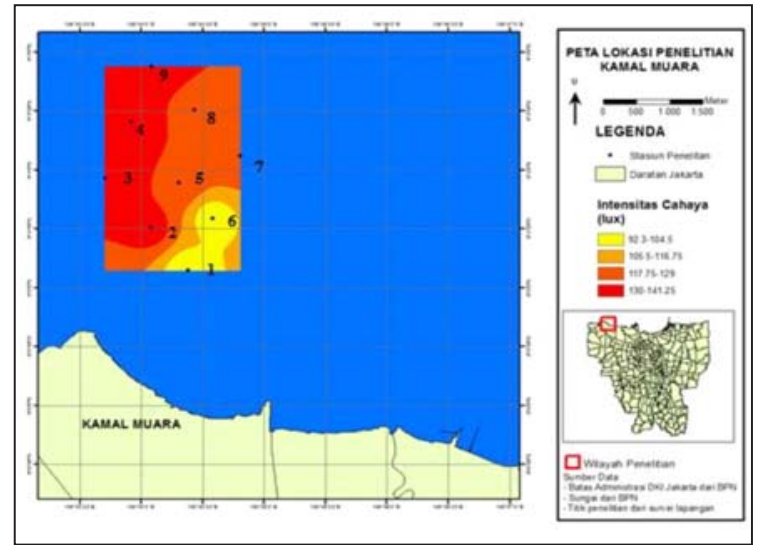

Figure 10. Light intensity distribution map

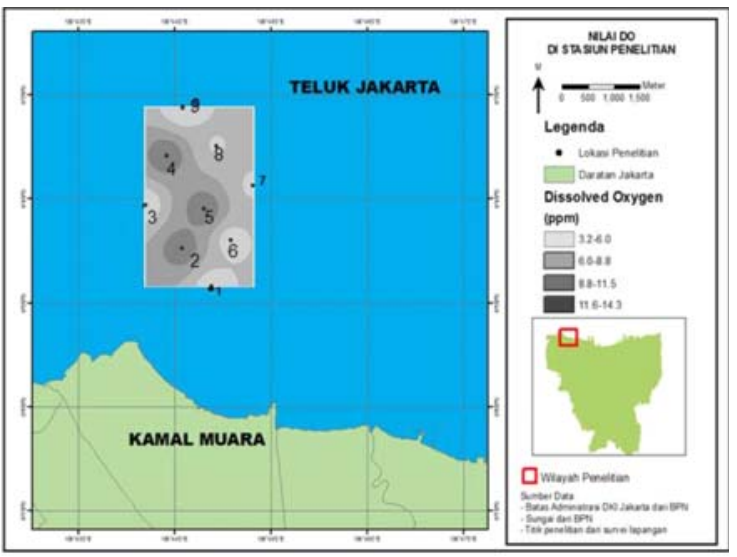

Figure 12. DO distribution map.

Based on its correlation value, Cyanophyceae abundance in the sampling sites was more influenced by phosphate. The distribution of Cyanophyceae abundance map (Fig. 4) and the distribution map of phosphate concentration (Fig. 5) illustrates that the relatively high phosphate content is not in line with the abundance of Cyanophyceae. Cyanophyceae abundance occurred at Station 4, Station 5, and Station 9, with 6 cells/liter, 16 cells/liter, and 15 cells/liter, respectively. Phosphate concentration in the three stations was lower than other stations, with $1.05 \mathrm{mg} /$ liter, $1.09 \mathrm{mg} / \mathrm{liter}$, and $0.62 \mathrm{mg} / \mathrm{liter}$, respectively. Trichodesmium as the most abundant genus in class Cyanophyceae in the research area is known to be able to grow optimally in water that has a high phosphate concentration (Sellner, 1997).

\section{SUMMARY}

Thalassiosira and Chaetoceros (Bacillariophyceae) are two genera that had the highest abundance in the sampling sites, followed by Ceratium and Protoperidinium (Dinophyceae). The highest phytoplankton abundance occurred at stations close to the mainland (Station 1 and Station 2). Some species, like Thalassiosira spp., Chaetoceros covanicornis, and Ceratium fusus can cause adverse effects on the environment and green mussel. The abundance of Bacillariophyceae was mostly influenced by $\mathrm{pH}$, while Dinophyceae was influenced 
by salinity, and Cyanophyceae by phosphate.

\section{RECOMENDATION}

The location of aquaculture sites for the green mussel should be located far from the mainland, considering that several harmful species from class Bacillariophyceae and Dinophyceae are most abundantly found in the areas near mainland.

\section{ACKNOWLEDGMENT}

The authors express gratitude to Universitas Indonesia for research funding, Mrs. Titi Soedjiarti, and Mrs. Dian Hendrayanti for the valuable suggestions, and the fisherman community in Kamal Muara for sampling accommodation. The authors would also like to thank research students at Marine Biology Laboratory, FMIPA-UI.

\section{REFFERENCE}

Anderson, D., P. Andersen, V.M. Bricelj, J.J. Cullen, and J. E.J. Rensel. 2001. Monitoring and management strategies for harmful algae blooms in coastal waters. APEC-IOCT, Singapura: ii + $268 \mathrm{hlm}$.

Asmara, A. 1999. Hubungan Struktur Komunitas Plankton Dengan Kondisi Fisika-Kimia Perairan Pulau Pramukadan Pulau Panggang, Kepulauan Seribu. Skripsi. Departemen Manajemen Sumberdaya Perairan, Fakultas Perikanan dan dan IImu Kelautan, Institut Pertanian Bogor, Bogor: ix $+81 \mathrm{hlm}$.

Dinas Peternakan, Perikanan dan Kelautan (DPPK) Provinsi DKI Jakarta. 2006. Kajian Eksistensi Budidaya Kerang Hijau di Teluk Jakarta. Penerbit CV. Srikandi Utama Konsultan, Jakarta: viii + 115 hlm.

Gomez, F. 2005. A list of free-living dinoflagellate species in the world's oceans. Acta Botanica Croatia, 64(1): 129-212.

Gross, G. M. 1990. Oceanography: A View of the Earth. $5^{\text {th }}$ ed. Prentice Hall, New Jersey: xiv $+441 \mathrm{hlm}$.

Hadikusumah. 2007. Variabilitas musiman Temperatur dan salinitas di Teluk Jakarta. Marine

Dynamic Division-Research Centre for Oceanography Indonesia Institute of Science (LIPI). Lingkungan Tropis, Edisi Khusus Agustus 33-41.

Hallegraeff, G.M. 1991. Aquaculturists guide toharmful Australian microalgae. Fishing Industry Traning Board of Tasmania, Tasmania: vii + $111 \mathrm{hlm}$.

Kurniawan, G. 2008. Studi Ekologi Kista Dinoflagellata Spesies Penyebab HAB (Harmful Algal Bloom) di Sedimen Pada Perairan Teluk Jakarta. Skripsi, Program Studi Teknologi Kelautan, Fakultas Perikanan dan IImu Kelautan, Institut Pertanian Bogor, Bogor: xii + $101 \mathrm{hlm}$.

McGinnis, K. M., T. A. Dempster. and M. R. Sommerfeld. 1997. Characterization of the growth and lipid content of the diatom Chaetocerosmuelleri. Journal of Applied Phycology. 9 (?): 19-24.

Parsons, T. R., M. Takahashi, and B. Hargrave. 1984. Biological Oceanographic Processes. $3^{\text {rd }}$ ed. Pergasson Press, Oxford: $x i+330 \mathrm{hlm}$. 
Praseno, D.P. 1995. A Study on HAB organism in Indonesian Waters. Proceedings of the International seminar on marine fisheries environment. 1 (1): 119-126.

Puspiptek Kemenristek RI. 2013. Kemenristek kembangkan jejaring pengelolaan limbah B3 industri di kawasan Tangerang Raya. http://puspiptek.ristek.go.id/media.php? module=detailberita\&id=1845-kemenristek-kembangkan-jejaring-pengelolaanlimbah-b3-industri-di-kawasan-tangerang-raya.html. Accessed 20 March 2013.

Sellner, K.G. 1997. Physiology, ecology, and toxic properties of marine Cyanobacteria blooms. Lymnology and Oceanography. 41 (5): 1089-1104.

Su, H. M., Y. M. Chiang, and I.C. Liao. 1993. Role of temperature, salinity, and Ammonia on the occurrence of the Taiwanese strain of Alexandriumtamarense. In: Smayda, T.J., and Y. Shimizu (editors.). 1993. Toxic Phytoplankton in the Sea. Elsevier Science Publishers, Amsterdam: 837-842.

Suthers, I. M., and D. Rissik. 2009. Plankton: A guide to their ecology and monitoring for water quality. CSIRO Publishing, Collingwood: $x v+273 \mathrm{hlm}$. 